\title{
ASPEKTY WYCHOWAWCZE W PISMACH FILOZOFICZNYCH PLATONA I AUTORÓW CHRZEŚCIJAŃSKICH IV WIEKU (ŚW. AUGUSTYN, ŚW. HIERONIM)
}

W każdej epoce dziejów ludzkości, także i w czasach nam współczesnych, pojawiały się i pojawiają pytania dotyczące wychowania dzieci i młodzieży. Jesteśmy świadkami toczących się dyskusji, a nawet i sporów o to, kto ma wychowywać, w jaki sposób, jakie należałoby stawiać sobie cele wychowawcze etc. Wzrastająca w niepokojący sposób przestępczość wśród młodych pokazuje, iz w procesie wychowawczym coś się popsuło, a więc o czymś zapomniano lub świadomie odrzucono. Młody człowiek, który nie wszedł jeszcze na drogę przestępczą czuje się zagubiony i osamotniony. Proponowany przez niektórych styl życia, nastawiony na korzyść, przyjemność, nie daje pozytywnych efektów, ale wręcz przeciwnie, pogłębia kryzys wewnętrzny człowieka, który później manifestuje się jakże często w drastyczny sposób.

Stąd rodzi się problem i jednocześnie pytanie o to, czy zamiast eksperymentować na żywym organizmie, jakim jest człowiek, nie sięgać do dawnych, sprawdzonych i zawsze aktualnych wzorców wychowawczych, trudnych, ale jakże skutecznych nie tylko w czasach nowożytnych, ale także i w starożytności. Innymi słowy, w niniejszym opracowaniu postaramy się, choć w sposób niewyczerpujący do końca tematu, przede wszystkim z uwagi na ramy, które wyznacza artykuł, poszukać odpowiedzi na tak postawione pytanie. Szukać jej będziemy w wybranych pismach Platona (427-347), ucznia i wychowanka Sokratesa, a także Ojców Kościoła złotego okresu patrystyki, Augustyna (354-430) i Hieronima (ok. 340-420).

Stosując metodę analityczno-porównawczą proponowany temat rozpatrzymy w czterech aspektach. Najpierw zastanowimy się nad wychowaniem jako obowiązkiem, następnie postaramy się dokonać oceny procesu wychowawczego, by potem omówić cele i metody wychowawcze.

\section{WYCHOWANIE JAKO OBOWIAZZEK}

Starożytność niechrześcijańska, którą reprezentuje tutaj Platon, jak i ta chrześcijańska Ojców Kościoła, podobnie jak dzisiaj, stawiała sobie pytanie 
o to, kto ma wychowywać dzieci i młodzież, i czy jest to tylko obowiązkiem rodziców czy też domeną państwa. W takiej też kolejności postaramy się przybliżyć te zagadnienia.

1. Obowiązek rodziców. Do obowiązku rodziców jak i wychowawców należy, zdaniem Platona, wychowanie dzieci ${ }^{1}$, gdyż, jak to zauważa z kolei Augustyn, rodzice przyjmując potomstwo $\mathrm{z}$ miłością, dbają o nie $\mathrm{z}$ dobrocią i pobożnie wychowują ${ }^{2}$; spełniają to, co stanowi ich zadanie ${ }^{3}$, przekazują, jak to zaznacza Platon, mówiąc o ateńskim mężu stanu Temistoklesie (527-459), mądrość ${ }^{4}$, nie szczędząc, jak historyk grecki Tukidydes (460- ok. 393) na to pieniędzy ${ }^{5}$.

Zagadnienia obowiązku wychowywania dzieci przez rodziców nie pomijał także Hieronim. W swych wypowiedziach zawartych na przykład w liście adresowanym do wdowy Salwiny przypomina jej o obowiązku wychowania dzieci, które pozostawił jej zmarły mąż. Poprzez wypełnienie tego zadania, zdaniem autora listu, odda ona swym dzieciom to, co winna dać małżonkowi ${ }^{6}$, sam zaś proces wychowania winien być, jak to podkreśla w innym miejscu, godny pochodzenia dziecka ${ }^{7}$. Hieronim mówiąc o wychowaniu równocześnie uzasadnia swe stanowisko, podkreślając znaczenie szczególnej odpowiedzialności, jaka ciąży na rodzicach, nie tylko za dorosłe i samodzielne dzieci, ale przede wszystkim za niedorosłe i słabe, które często nie dostrzegają różnicy pomiędzy dobrem a złem ${ }^{8}$.

Z kolei dla Platona proces rodzenia, jak i wychowania dzieci, jest przekazywaniem życia w następne pokolenia i zgodną z prawami służbą bożą ${ }^{9}$. Podobne stwierdzenia spotkać możemy u Augustyna, który jest zdania, że czymś bardzo wielkim jest przyjąć dziecko, wykarmić narodzone, wychować i doprowadzić je do wieku młodzieńczego ${ }^{10}$.

${ }^{1}$ Por. Protagoras 325c-326e, Respublica, 454d-457b, przekład polski: W. Witwicki (Państwo, t. I i II, Warszawa 1948); zob. także P. Blomenkamp, Erziehung, RAC VI 504-506.

${ }^{2}$ Por. De Genesi ad litteram imperfectus liber 9, 12, PL 34, 233-235.

${ }^{3}$ Por. Enarrationes in Psalmos 50, 24, PL 36, 599; CCL 38, 615-616, thum. J. Sulowski, PSP 38, 289.

${ }^{4}$ Por. Menon 93d, przekład polski: Paweł Siwek (Warszawa 1991, PWN); zob. też Menon 94a, gdzie Platon pochwala Lizymacha ojca Arystydesa oraz Peryklesa ojca Paralosa i Ksantiposa za wychowanie, jakie dali swym dzieciom.

${ }^{5}$ Por. Menon $94 \mathrm{~cd}$.

${ }^{6}$ Por. Epistula 79, 7, PL 22, 728-730; CSEL 55, 94-96, przekład polski: J. Czuj (Sw. Hieronim, Listy, t. 1-3, Warszawa 1952-1954).

7 Por. Epistula 107, 3.

${ }^{8}$ Por. Epistula 107, 6.

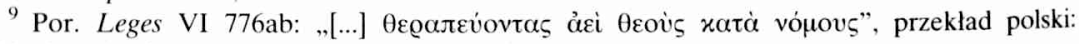
M. Maykowska (Prawa, Warszawa 1960, PWN).

${ }^{10}$ Por. Enarrationes in Psalmos 51, 7. 
2. Obowiązek państwa. Głębsza analiza pism Platona, w kontekście i na tle jego nauki o państwie, ukazuje jednak, iż tworząc obraz państwa idealnego przyznawał on jemu, w przeciwieństwie do Augustyna i Hieronima, dominującą rolę i obowiązek wychowywania dzieci i młodzieży. Zdaniem tego filozofa prawodawca winien czuwać nie tylko nad łączeniem się obywateli w związki małżeńskie, rodzeniem potomstwa, ale także nad wychowaniem tak chłopców jak i dziewczą ${ }^{11}$, którzy, jak to wynika z innej wypowiedzi autora, są wspólnym dobrem $^{12}$. Kontynuując swe refleksje autor uważa, że w życiu prywatnym i domu rodzinnym powstaje wiele zwyczajów, które nie zawsze są zgodne z tym, co zamierza wprowadzić prawodawca. Innymi słowy, Platon, pomimo że wypowiadał się na temat obowiązku rodziców w wychowywaniu dzieci i młodzieży, to jednak krytycznie odnosił się do wychowywania dzieci przez rodziców, które to, jego zdaniem, jest przyczyną tworzenia się rozbieżnych i niezgranych charakterów, usposobień, które są dla państwa niebezpiecz$\mathrm{ne}^{13}$. Dla tego autora jedyny wyjątek stanowi fakt śmierci męża, kiedy to małżonka winna, jak czytamy, pozostać w domu i zająć się wychowaniem dzieci. Ale i w tym przypadku Platon decydujące w ostateczności rozstrzygnięcia przyznał kobietom, którym w państwie zlecono pieczę nad sprawami małżeńskimi, i które wspólnie z krewnymi postanawiają o dalszym wychowaniu i kształceniu dzieci ${ }^{14}$.

Tak więc w idealnym państwie platońskim nie można mówić o wpływie rodziców na wychowanie i wykształcenie dziecka, nie brane są również pod uwagę zainteresowania samego wychowanka. Przeciwnie, także i w tych dziedzinach dostrzega się dominację państwa ${ }^{15}$. Tę myśl potwierdza wypowiedź, jaką autor wkłada w usta swego mistrza Sokratesa, który między innymi broniąc wyższości prawa państwowego, pochwalał jego ustawy odnoszące się do wychowania, wykształcenia w muzyce, literaturze, gimnastyce, a także utrzymania dzieci ${ }^{16}$.

\section{OCENA PROCESU WYCHOWAWCZEGO}

Ograniczenie się do oceny wychowania rozumianego tylko jako obowiązku jest niewystarczające. Wychowanie bowiem jest sztuką i to niełatwą. Dlatego

${ }^{11}$ Por. Leges I, 631d.

${ }^{12}$ Por. Respublica V 12, 465c; V 13, 466bd, przekład polski: W. Witwicki (Państwo, t. I i II, Warszawa 1948)

13 Por. Leges VII, 788ab.

${ }^{14}$ Por. Leges XI, 930c.

15 Por. Leges VII, 810a.

${ }^{16}$ Por. Kriton XII, 50d, przekład polski: W. Witwicki (Warszawa 1988 PWN). 
też ten kolejny punkt opracowania chcemy poświęcić temu zagadnieniu uwzględniając także zagrożenia, jakie towarzyszą procesowi wychowawczemu.

1. Wychowanie jako sztuka. Lektura Platońskiego Państwa pozwala zauważyć, iż dostrzegał on konieczność powszechności wychowania ${ }^{17}$ i równości obowiązków, w tym wojskowo-politycznych ${ }^{18}$. Ta propozycja, jak zauważa Reale $^{19}$ była w środowisku greckim czymś nowym, gdyż w tych czasach kobieta nie zajmowała się działalnością kulturalną czy polityczną, ale prowadziła gospodarstwo domowe i wychowywała dzieci. Platon tworząc swą koncepcję idealnego państwa dostrzegł potrzebę zaistnienia w nim między innymi stróżów, którzy winni być poddani właściwemu dla ich stanowiska wychowaniu. W tym celu uczeń Sokratesa proponował dokonanie reformy wychowania i kształcenia ${ }^{20}$ po to, by przekazywać treści pod względem moralnym przyzwoite i prawdziwe, gdy chodzi o opowiadania o bogach ${ }^{21}$. Reformie poddał też takie dziedziny, jak na przykład muzyka ${ }^{22}$ czy gimnastyka ${ }^{23}$.

$\mathrm{Z}$ wypowiedzi pism naszych chrześcijańskich autorów również wynika, że sam proces wychowawczy wymaga wielkich umiejętności, psychologicznego, jak to byśmy dziś powiedzieli, podejścia do człowieka. Przykładem mogą być tu spostrzeżenia Hieronima, który w jednym ze swych listów podaje wskazówki na temat, jak uczyć małe dziecko mówienia i czytania, łączenia tego co pożyteczne, z tym co przyjemne, zwłaszcza, gdy nie zawsze ma ono do nauki ochotę. Dla tego Ojca Kościoła istotnym jest, by dziecko pokochało to czego ma się uczyć, by to czego się uczy, jak czytamy, było nie tyle pracą, co przyjemnością, zajęciem wykonywanym nie z konieczności, ale $\mathrm{z}$ ochoty ${ }^{24}$. Innymi słowy, nie można dopuścić, by dziecko znienawidziło naukę i czuło do niej przez całe życie wstręt ${ }^{25}$. Te wskazania, naszym zdaniem, można odnieść nie tylko do rodziców, ale także do wychowawców. Innymi słowy, poprawność przebiegu procesu wychowawczego u dziecka wymaga obecności właściwych, jak zauważa Platon, doświadczonych i odpowiednich wiekiem wychowawców ${ }^{26}$. Ten-

${ }^{17}$ Por. Respublica IV, $444 \mathrm{~d}$.

${ }^{18}$ Por. Respublica V 455d-456a; VII 540c.

19 Por. G. Reale, Storia della filosofia antica, t. II: Platone e Aristotele, Milano 1992², 281-355, przekład polski: E. Zieliński (Historia filozofii starożytnej, II: Platon i Arystoteles, Lublin 1996), 287-326.

${ }^{20}$ Por. Respublica II 376d.

21 Por. Respublica II 377b; III 398a.

22 Por. Respublica III 398c.

23 Por. Respublica III 403cd.

24 Por. Epistula $128,1$.

25 Por. Epistula 107, 4.

${ }^{26}$ Por. Respublica V 14, 467d. Potwierdzenie tego znajdujemy również w Leges 6, 765d, gdzie autor zaleca by naczelnym kierownikiem wychowania młodzieży męskiej i żeńskiej był ojciec pięćdziesięcioletni ślubnych dzieci jednej czy drugiej płci, a najlepiej synów i córek. 
że filozof ma świadomość, że dziecko nie może być pozostawione samemu sobie, nie może ono kierować sobą samym, gdyż to zadanie należy do wychowawcy $^{27}$.

Rozumiał to również Hieronim, który był przekonany, iż dziecku należy nie tylko dobierać odpowiedniego, godnego wiekiem, życiem i wykształceniem nauczyciela, ale także poważnego wychowawcę, gdyż w dzieciństwie nie powinno się ono uczyć tego, czego później z trudem, będzie się musiało oduczyć ${ }^{28}$. Potwierdza to także Augustyn, z którego wypowiedzi wynika, iż jego matka swe dobre wychowanie zawdzięczała przede wszystkim troskliwości sędziwej służącej, do której rodzice Moniki odnosili się z respektem, jak do szacownego członka chrześcijańskiej rodziny powierzając jej wychowanie swych córek, co wykonywała sumiennie i roztropnie przygotowując je do trzeźwego, jak czytamy, życia pozbawionego złych nawyków, a nawet i nałogów ${ }^{29}$. Nie budzi więc zdziwienia fakt, iż Hieronim takiego wychowawcę czy rodzica uważa za godnego zasłużonej pochwały ${ }^{30}$. Czynił to także Platon chwaląc strażników za to, że urodzili się w zacnych rodzinach i otrzymali dobre wychowanie ${ }^{31}$. Z pozytywną oceną ucznia Sokratesa spotkał się więc Antemion, który dobrze wychowywał i kształcił swego syna ${ }^{32}$, za to też został pochwalony Lysimach i Perykles ${ }^{33}$.

W procesie wychowawczym dziecka ważną rolę odgrywa udzielana mu przez rodziców czy wychowawców pochwała. Tak postępował Augustyn wobec swego syna, chwaląc go za bystrość umysłu, posiadane talenty czy inteligencję $^{34}$ oraz Hieronim, który adresatce listu przypomina, by starała się pochwałami podniecać zdolności w tym celu, aby córka cieszyła się ze swych sukcesów a smuciła z powodu niepowodzen ${ }^{35}$. Rodzic czy wychowawca podejmując się wychowywania dziecka winien, zdaniem Hieronima, pamiętać, by ono poprzez wykonywanie różnorodnych czynności maksymalnie wykorzystywało czas $^{36}$, by także, jak to zauważa Augustyn, wychowanie miało charakter ustawiczny $^{37}$, a wykształcenie, co podkreśla Platon, było najlepsze ${ }^{38}$.

${ }^{27}$ Por. Lysis 4, 208c.

${ }^{28}$ Por. Epistula 107, 4.

${ }^{29}$ Por. Confessiones IX 8, przekład polski: Z. Kubiak (Św. Augustyn, Wyznania, Warszawa 1982), s. 163.

${ }^{30}$ Por. Epistula 125, 6; 130, 2.

31 Por. Leges XI, 920a.

32 Por. Menon 90ab.

33 Por. Menon 94a.

34 Por. Confessiones IX 6.

35 Por. Epistula 107, 4.

${ }^{36}$ Por. Epistula 107, 9.

${ }^{37}$ Por. De sancta virginitate 12, PL 40, 401; CSEL 41, 244-245.

${ }^{38}$ Por. Leges IX, 854e. 
2. Zagrożenia $\mathbf{w}$ procesie wychowawczym. Procesowi wychowawczemu towarzyszą jednak liczne zagrożenia. Dostrzegł to już Platon, który widział to niebezpieczeństwo na przykład w sztuce. W jego przekonaniu, sztuka nie odkrywa prawdy, ale ją zakrywa, gdyż nie poznaje, nie czyni człowieka lepszym, jest kłamliwa, nie wychowuje, lecz psuje efekty wychowania, ponieważ zwraca się do nierozumnych władz duszy ${ }^{39}$, które są niższymi częściami człowieka, jest naśladownictwem naśladownictwa, kopią kopii, daleka od prawdy ${ }^{40}$. Stąd też, jego zdaniem, należy ją ograniczyć lub usunąć, chyba, że podporządkuje się ona prawom dobra i prawdy ${ }^{41}$. Innymi słowy, w kontekście jego filozofii, dla której nadrzędną wartością było Dobro i Jedno, sztuka będzie miała wartość o tyle, o ile będzie służyła prawdzie, a więc będzie podporządkowana najwyższym i pierwszym zasadom. To jednak może zrealizować podporządkowując się filozofii, która umie docierać do prawdy samej w sobie. Mówiąc jeszcze inaczej, proces wychowawczy, w rozumieniu Platona, będzie zawsze nieskuteczny wtedy, gdy pomijać będzie Najwyższą Prawdę.

Na tle tych przemyśleń zrozumiała wydaje się jego uwaga praktyczna, z której wynika, że w zależności od tego, jacy będą synowie, tak będzie zagospodarowany cały dom ojcowski ${ }^{42}$. Rodzic, jak możemy się przekonać z lektury pism platońskich, nie może być obojętny wobec przyszłego losu swych dzieci ${ }^{43}$. Złe wychowanie dziecka, brak zainteresowania się nim, zwłaszcza środowiskiem, w którym przebywa, ludźmi, z którymi się spotyka, jest, jak to wynika z przemyśleń naszego filozofa, powodem tego, że taki człowiek nie będzie ani dzielnym żołnierzem, ani też nie będzie potrafił rządzić państwem i gospodarzyć $\mathrm{w}$ mieście ${ }^{44}$. Brak umiejętności wychowawczych odbija się także negatywnie na psychice dziecka, w którym, jak to podkreśla Platon, zaczynają się mnożyć pożądania, pokrewne wygnanym ${ }^{45}$. Nie tylko staje się ono apodyktyczne wobec otoczenia ${ }^{46}$, ale także w sytuacji, gdy ojciec zajmuje się pomnażaniem majątku dla synów, ci wychowani przez niewiasty, nie będąc zaprawieni do trudów życiowych, nie będą umieli stawić czoła przeciwnościom, które przynosi życie ${ }^{47}$.

39 Por. Respublica X 603ab.

40 Por. Respublica X 598b; 602ab.

41 Por. Respublica II; X.

42 Por. Laches IX, 185a, przekład polski: W. Witwicki (Warszawa 1958 PWN).

43 Por. Kriton V $45 \mathrm{~cd}$.

${ }^{44}$ Por. Leges II 666e.

45 Por. Respublica VIII 13, 560e.

46 Por. Leges III 694de.

${ }^{47}$ Por. Leges III 695e. 


\section{CELE WYCHOWAWCZE}

Platon zobowiązując rodziców i nauczycieli do wychowywania dzieci ${ }^{48}$, postawił przed nimi ideał wychowawczy, jakim jest $x \alpha \lambda o x \alpha ̉ \gamma \alpha \theta i \alpha$, czyli zgodność, harmonia ducha i ciała. Innymi słowy, temu starożytnemu autorowi chodziło o to, by człowiek w swym rozwoju nie tylko dochodził do piękna fizycznego, ale i duchowego. Tę myśl pogłębia jego inna wypowiedź zawarta w dziele Respublica ${ }^{49}$, z której wynika, iż wychowanie oznaczało dla niego dochodzenie do ỏ@ $\theta$ òs $\lambda$ ó $_{0} \varsigma^{50}$, rozumianego jako trafne poznanie ogólnej normy, którą jest Dobro samo w sobie ${ }^{51}$, do którego każdy winien dążyć.

Ojcowie Kościoła podejmując temat formacji człowieka również szukali dla niej punktu odniesienia, który stanowił, jak potwierdza to Augustyn, Dekalog, a więc prawo Boże, według którego każdy winien postępować ${ }^{52}$. Pisma wczesnochrześcijańskich autorów potwierdzają, iż wychowanie człowieka, a więc jego formacja, mając na uwadze określony przez nich punkt odniesienia, dotyczyła nie tylko jego strony fizycznej, ale również intelektualnej, filozoficznej, etycznej i duchowej. W takiej też kolejności postaramy się przybliżyć te zagadnienia.

1. Formacja fizyczna. $Z$ lektury pism naszych autorów wynika, że na temat formacji fizycznej człowieka wypowiadał się przede wszystkim Platon, który starał się przekonać, iż ciało stanie się najpiękniejsze, gdy w łonie matki ${ }^{53}$ i po urodzeniu będzie się rozwijać we właściwy sposób, bez dolegliwości i cierpień, a więc bez gwałtownego wzrostu i z pominięciem wysiłku ${ }^{54}$. Nie może więc dziwić jego pochwała, adresowana do wspominanego już przez nas Tukidydesa za to, że swych synów, Melezjasa i Stefanosa, uczynił najlepszymi zapaśnikami, a to dzięki temu, że posyłał ich do sławnych pod tym względem nauczycieli $^{55}$. Na tle tej wypowiedzi nie bez znaczenia są jego życzenia kierowane do rodziców, by swych synów, także poprzez obserwacje działań wojennych, naukę jazdy konnej ${ }^{56}$, uczenie różnych sposobów walk ${ }^{57}$, przygotowywali do służby wojskowej ${ }^{58}$. Stróż bowiem państwa, według Platona, musi być poprzez

\footnotetext{
48 Por. Protagoras 325c-326e; zob. P. Blomenkamp, Erziehung, RAC VI 504.

49 Por. Respublica 454d-457b.

50 Por. Phaedo 73, przekład polski: W. Witwicki (Warszawa 1988, PWN).

51 Por. komentarz Danieli Gromskiej do Etyki nikomachejskiej Arystotelesa, w: Arystoteles, Dzieła wszystkie, t. 5, Warszawa 1996, s. 105, przypis 5.

52 Por. Enarrationes in Psalmos 73, 2.

53 Por. Leges VII 789a.

54 Por. Leges VII 788d; VII, 790cd.

55 Por. Menon 94cd.

56 Por. Respublica V 14, 467c; 14, 467e; Menon 93d, 94b.

57 Por. Menon 94b.

58 Por. Respublica V 14, 467e.
} 
uprawianą gimnastykę fizycznie mocny ${ }^{59}$. Ta jednak musi być prosta ${ }^{60}$ i zajmować miejsce tuż po wychowaniu duszy, gdyż ta dopiero będąc dobrą dzięki swej cnocie, może ciało uczynić dobrym, a nie odwrotnie ${ }^{61}$. Innymi słowy, w opinii Platona ostatecznym celem gimnastyki nie tyle było udoskonalenie sprawności fizycznej ciała, co tego elementu duszy, który jest źródłem cnoty odwagi $^{62}$.

Tak więc w myśl założeń ucznia Sokratesa, wychowanie gimnastyczne poprzez ciało, miało za zadanie formować i wzmacniać gniewliwą część duszy, a w połączeniu z wychowaniem muzycznym wytworzyć w człowieku doskonałą harmonię. Należy jednak podkreślić, iż w świetle nauki Platona, kształtowanie sprawności fizycznej przyszłego wodza, było jednak tylko momentem przygotowawczym, wytwarzało skutki Dobra, ale nie dawało jeszcze jego poznania tak bardzo potrzebnego wodzowi w urzeczywistnianiu idealnego państwa, a które to umożliwiała dopiero formacja filozoficzna.

2. Formacja intelektualna. W przekonaniu Platona przyszły przywódca państwa, jakim ma być filozof, musi zapoznać się z zasadami matematyki nauczanej w formie zabawy ${ }^{63}$ oraz geometrii, astronomii i harmonii, ponieważ te nauki zmuszają człowieka do posługiwania się rozumem oraz prowadzą do kontaktu rozumowego $z$ uprzywilejowaną częścią bytu, jakim są byty i prawa matematyczno-geometryczne.

Wypowiadając się nad programem nauczania, Platon wyraźnie określił nieprzekraczalne, (pomimo na przykład pragnień ojca czy samego zainteresowanego) granice wieku, w którym dziecko winno rozpoczynać naukę pisania i czytania (dziesięć lat) oraz gry na lutni (trzynaście lat), a także jej ukończenia, które miało miejsce w szesnastym roku życia ${ }^{64}$. Do zakresu obowiązujących przedmiotów zaliczał nasz filozof także dialektykę, ponieważ ta pozwala oderwać się od tego, co zmysłowe, i dojść do czystego bytu idei, a poprzez nie do oglądu Dobra, a więc największego poznania i celu wszelkiego poznania ${ }^{65}$. Był przeciwny, jak to już powiedzieliśmy w poprzednim paragrafie, sztuce. Konsekwencją tego było jego negatywne nastawienie $z$ tych samych względów do poezji przed którą przestrzegał wychowanków ${ }^{66}$.

Porównując wypowiedzi Platona z tym, co przekazuje nam na przykład Hieronim, musimy przyznać, że również ten autor chrześcijański zalecał rodzi-

\footnotetext{
59 Por. Respublica II 375a.

${ }^{60}$ Por. Respublica III 403c.

${ }^{61}$ Por. Respublica III 403d.

${ }^{62}$ Por. Respublica III $410 \mathrm{~b}$.

63 Por. Respublica VII 536d-537a.

${ }^{64}$ Por. Leges VII 810a.

65 Por. Respublica IV 435d; VI 503e-504e.

${ }^{66}$ Por. Menon 99d; Faidros 244a, 245 a.
} 
com, by pamiętali o formacji intelektualnej swych dzieci. Nawiązując do pism rzymskiego nauczyciela wymowy Marka Fabiusza Kwintyliana (ok. 35-95), starał się adresatce listu podać sposoby uczenia dzieci czytania i pisania ${ }^{67}$, także poprzez zabawę i rywalizację z innymi, przypominając, że do wymowy słynnych Grakchów przyczyniła się w dzieciństwie ich matka, zaś mówcę Hortensjusza (114-50) tej sztuki uczył jego ojciec ${ }^{68}$. Jego zdaniem, dziecko winno także każdego dnia poznawać rytm greckich wierszy, uczyć się łaciny już od młodości po to, by wymowa nie przybierała obcego brzmienia, a język ojczysty nie był zeszpecony obcymi naleciałościami ${ }^{69}$. W swych wskazaniach przypominał także, iż nie tylko należy chronić dziecko przed przyswajaniem przez nie niewłaściwych słów i pieśni, nie należy też (tu widać różnicę z Platonem) poznawać i słuchać instrumentów muzycznych ${ }^{70}$, ale trzeba zapoznawać je z pięknem Psalmów w tym celu, by przez nie tak ukształtowana dusza człowieka, stała się świątynią Pana ${ }^{71}$.

Analiza tych wypowiedzi pozwala jednak dostrzec pewne podobieństwa między przemyśleniami Platona i Hieronima. Wynika z nich, że formacja intelektualna nie była celem sama w sobie. Tym celem dla Platona było w wymiarze ontologicznym Summum Bonum, dla Hieronima - Bóg, zaś w społecznym i etycznym, jak to jeszcze zobaczymy, u Platona - przywódca państwa, dobry człowiek $^{72}$, u Ojców Kościoła - dobry człowiek i jednocześnie chrześcijanin, a nie tylko, jak to krytycznie ocenia Augustyn, ktoś, kto dzięki nauce zdobył wysoką pozycję społeczną, która umożliwia mu organizowanie igrzysk ${ }^{73}$.

3. Formacja filozoficzna. W świetle cytowanych pism naszych autorów musimy zauważyć, iż temu zagadnieniu uwagę poświęcił jedynie Platon. Z lektury jego wypowiedzi wynika, iż warunkiem urzeczywistnienia idealnego państwa jest to, by rządzący stali się filozofami, albo filozofowie rządzącymi, gdyż jedynie ci mogą dać teoretyczne jego podstawy i będą w stanie je zrealizować ${ }^{74}$. Innymi słowy, filozof, który buduje państwo, jest tym, który kocha prawdę i mądrośćc ${ }^{75}$, a więc uznaje za najwyższą miarę, model i jego fundament to, co boskie i absolutne, a więc Summum Bonum, Dobro samo w sobie ${ }^{76}$, według

${ }^{67}$ Por. Epistula 107, 4; 128, 1; Quintilianus, Institutio oratoria I 2, 27-28.

${ }^{68}$ Por. Epistula 107, 4; 128, 1; Quintilianus, Institutio oratoria I 1, 6.

${ }^{69}$ Por. Epistula 107, 9, CSEL 55, 300: ,,[... ] ediscat graecorum versuum numerum. Sequatur statim et latina eruditio; quae si non ab initio os tenerum conposuerit, in peregrinum sonum lingua corrumpitur et externis vitiis sermo patrius sordidatur"; Quintilianus, Institutio oratoria I 1, 13.

70 Por. Epistula $107,8$.

71 Por. Epistula 107, 4; 128, 1.

72 Por. Menon 94b.

73 Por. Confessiones I 10.

${ }^{74}$ Por. Respublica VI 499bd.

75 Por. Respublica II 375a.

${ }^{76}$ Por. Respublica VI 505a; VII 540ab. 
którego kształtuje siebie i państwo ${ }^{77}$. Tak więc poprzez filozofa w platońskim państwie idea Dobra miała wkraczać do społeczności ludzkiej. Idea ta mając charakter boski dzięki działaniu filozofa, który drogą rozumową ją poznaje, stała się $w$ ten sposób nie tylko fundamentem bytu oraz życia człowieka w wymiarze indywidualnym, ale podstawą życia ludzi w wymiarze społecznym i politycznym, a więc prawdziwą podstawą państwa ${ }^{78}$. Zrozumiałe jest więc dlaczego Platon kształcenia i wychowania człowieka nie ograniczał tylko do sfery fizyczno-intelektualnej, ale dążył do tego, by na czele państwa stali filozofowie, gdyż tylko oni, jego zdaniem, poprzez formację filozoficzną dochodzą do poznania Dobra w nim samym ${ }^{79}$ i mogą je praktycznie urzeczywistniać.

Praktycznie wyglądało to tak, że młodzi w wieku dwudziestu lat, którzy wyróżniali się osiągnięciami w studiach, byli wychowywani do zrozumienia podobieństw zachodzących między dyscyplinami poznawanymi w poprzednim cyklu oraz do zrozumienia podobieństwa między tymi dyscyplinami a naturą bytu. W drugim cyklu nauki trwającym od dwudziestego do trzydziestego roku życia wychowawcy zobowiązani byli do upewnienia się, którzy z ich wychowanków posiadają naturę dialektyczną ${ }^{80}$, a więc zdolność oglądu całościowego

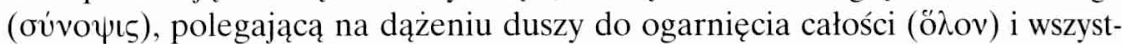
kiego $(\pi \tilde{\alpha} v)^{81}$. W wieku trzydziestu lat, ci którzy udowodnili, że posiadają naturę dialektyczną oraz potrafią oderwać się od zmysłów i skierować się ku bytowi samemu, zostawali poddani próbie ${ }^{82}$, a po jej pomyślnym zakończeniu, byli wychowywani $w$ dialektyce ${ }^{83}$. Pomiędzy trzydziestym piątym a pięćdziesiątym rokiem życia stawali się nie tylko dowódcami wojsk, ale można im było powierzać także inne zadania do wykonania.

Zakończenie formacji filozoficznej było przewidziane na pięćdziesiąty rok życia ${ }^{84}$. Od tego momentu filozof, który doszedł do poznania i kontemplacji Dobra samego w sobie, nie mógł tego zachować tylko dla siebie, ale był zobowiązany dzielić się tym z innymi, spłacając w ten sposób dług wychowania zaciągnięty wobec państwa. To dzielenie się polegało na trosce o innych, ukazywaniu korzyści płynących z oglądania Dobra. W idealnym państwie Platona było nie do pomyślenia, by jedni tylko przeżywali szczęście. Przeciwnie, poszczególne klasy, na które było ono podzielone, winne były się wzajemnie ubogacać ${ }^{85}$. W ten sposób sprawowana władza była służbą tych, którzy kon-

\footnotetext{
77 Por. Respublica VI 500b-501c.

78 Por. Respublica VI; VII passim; zob. Reale, dz. cyt., t. I, s. 281-355.

${ }^{79}$ Por. Respublica VI 504d.

${ }^{80}$ Por. Respublica VII 537c.

81 Por. Respublica VI 486.

${ }^{82}$ Por. Respublica VII 537d.

83 Por. Respublica VII 539e.

${ }^{84}$ Por. Respublica VII 540ab.

${ }^{85}$ Por. Respublica VII 520e-521b.
} 
templując Dobro, naśladując Demiurga, wprowadzali je do rzeczy, a poprzez swą działalność polityczną dzielili się nim z innymi.

4. Formacja etyczna. Treści przekazane przez naszych autorów pozwalają nam na stwierdzenie, iż dużo uwagi poświęcali oni formacji etycznej. W procesie wychowawczym chodziło im bowiem, jak to zauważa Platon, o uksztaltowanie dobrego ${ }^{86}$ pod względem etycznym człowieka, który, jak potwierdzają to Ojcowie Kościoła, bogaty jest w posiadane cnoty. Dokumentuje to wyraźnie wypowiedź Augustyna, który w swych Confessiones wspomina wyraźnie o swej matce, iż ta wychowana była w skromności i umiarkowaniu ${ }^{87}$, których przestrzegania w życiu nauczyła się, jak czytamy, w szkole serca, w której Bóg był dla niej Mistrzem ${ }^{88}$. Cnotę skromności, wstydliwości ${ }^{89}$, wstrzemięźliwości polegającej na tym, że nie zna się przedmiotu swych zachcianek ${ }^{90}$ i powściągliwości $^{91}$ nie tylko pochwalał, ale i zalecał jej posiadanie także Hieronim. Potwierdza to jego list, w którym podaje szczegółowe wskazania odnośnie stroju, kontaktów towarzyskich, a nawet ilości spożywanego pokarmu, by nie popaść w pożądliwośćc ${ }^{22}$, czy, jak to czytamy u Augustyna, w łakomstwo ${ }^{93}$, których dziecko winno się nauczyć przestrzegać ${ }^{94}$. Tenże Ojciec Kościoła z uznaniem wypowiada się o matce, która dzięki swej troskliwości wychowała swą córkę w dochowaniu cnoty dziewictwa ${ }^{95}$.

Ważnym elementem w formacji etycznej dziecka jest też jego wychowanie ku trzeźwości. Pisze na ten temat Augustyn, wypowiadając słowa pełne uznania pod adresem opiekunki dzieci w jego rodzinnym domu, która, jak czytamy, w razie konieczności surowo je karciła powołując się na prawo Boże, a przez rozsądne pouczenia przygotowywała je do trzeźwego życia ${ }^{96}$. Stąd też, podobnie jak Hieronim, pochwala zakaz spożywania przez dzieci, poza skromnymi posiłkami przy stole rodziców, dodatkowych pokarmów ze względu na to, by nie rozwinęły się w nich złe nawyki, a w przyszłości nawet nałóg pijaństwa ${ }^{97}$. Analizując te wypowiedzi biskupa Hippony można uznać, iż nakreślony cel pedagogiczny został osiągnięty, ponieważ dzieci nie pragnęły tego co było niegodziwe ${ }^{98}$.

\footnotetext{
${ }^{86}$ Por. Menon $94 \mathrm{~b}-\mathrm{d}$.

${ }^{87}$ Por. Confessiones IX 9.

88 Por. tamże.

${ }^{89}$ Por. Epistula 107, 7.

${ }^{90}$ Por. Epistula 107, 8.

${ }^{91}$ Por. Epistula 128, 1.

92 Por. Epistula 107, 8.

93 Por. Confessiones IX 8.

${ }^{94}$ Por. Hieronymus, Epistula 107, 5. 9-10.

${ }^{5}$ Por. Hieronymus, Epistula 22, 20.

96 Por. Confessiones IX 8.

${ }^{97}$ Por. tamże.

${ }^{98}$ Por. tamże.
} 
Nie brakuje również pod tym względem uwag ze strony Hieronima, który nie tylko wyklucza obecności dzieci podczas biesiad rodziców, ale także przestrzega przed uczeniem się spożywania wina, choć z drugiej strony dopuszcza, ale $w$ granicach wyznaczonych rozsądkiem i potrzebami zdrowotnymi ${ }^{99}$. Śledząc wypowiedzi naszych autorów, a zwłaszcza Augustyna, możemy również zauważyć, iż proces formacji etycznej w starożytności wymagał, z jednej strony od ojca wychowywania dziecka w karności, by w ten sposób nabierało ono wartości ${ }^{100}, \mathrm{z}$ drugiej zaś zachowywania przez dziecko dyscypliny ${ }^{101}$.

Kolejnymi wartościami, których uczono w starożytności, były te, o których wspomina Platon. Nie tylko, naszym zdaniem, pod wpływem szkoły pitagorejskiej zalecał, aby w idealnym państwie wychowanie młodych uwzględniało również naukę milczenia $\mathrm{w}$ obecności starszych ${ }^{102}$, ale także przypominał o ćwiczeniu się w zdobywaniu cnoty męstwa ${ }^{103}$, czci i szacunku wobec bogów i rodziców ${ }^{104}$.

Temu zwłaszcza ostatniemu zagadnieniu, poświęcił, jak możemy się przekonać, więcej uwagi. Wypowiadając się bowiem na temat obecności kultu w państwie wyraźnie zaznaczył, że po nakazanym prawem kulcie wizerunków bóstw rodowych w prywatnych domach, należy okazywać cześć żyjącym jeszcze rodzicom (na co zwracał również uwagę Hieronim) ${ }^{105}$, którym dzieci zawdzięczają pierwsze i największe dobrodziejstwa. Stąd też uważa, że obowiązkiem dzieci jest spłacać im te długi i stale pamiętać, że cokolwiek posiadają, należy do tych, którzy je zrodzili i wychowali, a w miarę możliwości, wszystko należy oddać na ich usługi, a więc majątek, siły fizyczne, umiejętności i zdolności, po to „by ten dawny wkład starań, przeogromnych trudów i udręk włożony w ich dzieciństwo, zwrócić im w ich sędziwym wieku, gdy tego tak bardzo potrzebują w starości". Należy również, jego zdaniem, przez całe życie zachowywać powściągliwość w słowach, z którymi zwraca się do rodziców, „pilnie strzec, by nigdy nie mieć tu sobie nic do wyrzucenia, gdyż łatwo wymykające się i lotne słowa ściągają najcięższą karę" ${ }^{106}$.

Wychowanie dzieci nie pomijało również tak ważnego i stale aktualnego problemu, jakim jest troska o kulturę osobistą, o czym obszernie na ten temat wypowiada się na przykład Hieronim ${ }^{107}$, gdy mówi o dbałości o czystość i piękno języka ojczystego ${ }^{108}$, nie przywiązywanie wagi do wartości tylko ma-

${ }^{99}$ Por. Epistula 107, 8.

100 Por. Enarrationes in Psalmos 88, (2) 2.

101 Por. Enarrationes in Psalmos 50, 24.

102 Por. Respublica IV 4, 425b.

103 Por. Leges VII 791c.

104 Por. Respublica III 1, 386a; IV 4, 425b.

105 Por. Epistula 125, 6.

106 Por. Plato, Leges IV 717bc, thum. M. Maykowska s. 160-161.

107 Por. Epistula 107, 4.

108 Por. Epistula 107, 9; 125, 6. 
terialnych, co potwierdza z kolei Platon, gdy mówi, że dzieciom należy przekazać w spuściźnie poczucie honoru, a nie złoto ${ }^{109}$. Nie bez znaczenia jest także zachęta Hieronima, by dzieci wykonywały drobne prace domowe, które kiedyś będą im przydatne w życiu już jako dorosłym ludziom ${ }^{110}$.

5. Formacja duchowa. Wychowanie człowieka, jak to wynika z lektury pism naszych autorów, nie może tylko ograniczać się do sfery fizycznej czy intelektualnej, ale musi być wychowaniem całościowym, obejmującym także i ducha. Potwierdza to Platon, gdy głosi, że właściwym i pożytecznym wychowaniem ${ }^{111}$ jest takie, które najpiękniej kształtuje ciało i duszę ${ }^{112}$. Lektura platońskich dialogów przekonuje, iż ich autorowi chodziło przede wszystkim o to, by oczyścić duszę z fałszywych mniemań i doprowadzić poprzez prowadzony z wychowankami dialog do spotkania ich z prawdą, a więc najwyższym Dobrem. Ta troska o duszę, polegająca na jej oczyszczaniu, a więc odchodzeniu od tego, co zmysłowe, a zwracaniu się ku temu, co jest ponadzmysłowe i poznawalne tylko przy pomocy rozumu, a tym jest Dobro samo w sobie, powoduje również moralne nawrócenie człowieka.

Platon dokonując reformy wychowania ${ }^{113}$ był przekonany, iż nie tylko poezja winna być oczyszczona $z$ tego, co jest moralnie nieprzyzwoite i fałszywe, zwłaszcza gdy chodzi o rozumienie bóstwa ${ }^{114}$, ale także muzyka poprzez usunięcie z niej miękkich tonacji, które, jego zdaniem, czynią duszę zniewieściałą, podczas gdy zadaniem muzyki jest dodawanie odwagi podczas wojny, a spontaniczności w czasie pokoju ${ }^{115}$. Temu procesowi została również poddana gimnastyka ${ }^{116}$, która, jak już to mówiliśmy w poprzednich paragrafach, służć miała budowaniu w człowieku harmonii wewnętrznej oraz zgodności pomiędzy elementem cielesnym i duchowym.

Analizując z kolei wypowiedzi Ojców Kościoła i porównując je z nauczaniem Platona, można, naszym zdaniem, dopatrzeć się pomiędzy nimi pewnych zbieżności. Stwierdzenie na przykład Hieronima, iż tak należy kształtować duszę, by była ona świątynią Pana ${ }^{117}$, by człowiek żył jakby w ciele bez cia$\mathrm{fa}^{118}$, czy Augustyna, że należy płakać, gdy ktoś grzeszy, bo gorszy jest żywy niż

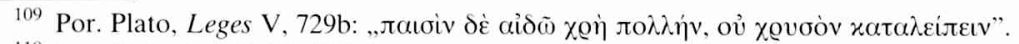

${ }^{110}$ Por. Epistula 107, 10; 128, 1.

111 Por. Leges VII, 790c.

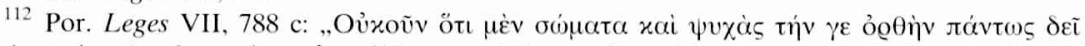

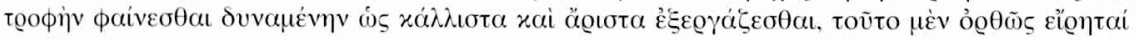
$\pi 0 v^{\prime \prime}$.

113 Por. Respublica II 376d; III passim.

114 Por. Respublica II 377b; III, 398a.

115 Por. Respublica III 398c.

116 Por. Respublica III 403c.

117 Por. Epistula 107, 4.

118 Por. Epistula 107, 13 
umarły, kiedy rozpustnie żyje, niż kiedy umrze kończąc rozpustę ${ }^{119}$, czyż nie jest dążeniem do budowania harmonii najpierw w sobie samym, a następnie z Bogiem? Jest prawdą, że Platon troskę o duszę uzasadnia tylko racjonalnie, zaś Ojcowie Kościoła rozpatrują to zagadnienie tak na płaszczyźnie racjonalnej, jak i na płaszczyźnie wiary i kontaktu osobowego z Bogiem, cele jednak wydają się być wspólne, a jest nim sam Bóg u Ojców, zaś u Platona boskie Dobro, które człowiek osiąga poprzez nawrócenie.

W ten nurt myśli wpisuje się Hieronim, przypominając o odpowiedzialności rodziców nie tylko za dorosłe, ale przede wszystkim za niedorosłe dzieci, kiedy to w jednym ze swych listów upomina adresatkę, iż zbytnio zabiega o bezpieczeństwo córki, gdy tymczasem winna troszczyć się o jej wnętrze: ofiarowanie córki Bogu, jak czytamy, leżało w gestii matki, zaś zaniedbywanie już ofiarowanej stanowi o jej winie ${ }^{120}$. Tenże Ojciec Kościoła zaleca, by dziecko nie tylko odrabiało zadania z Pisma św. i śpiewało psalmy ${ }^{121}$, ale także publicznie wykonywało różne praktyki pobożności ${ }^{122}$. Nie możemy tu również pominąć Augustyna, który wyznaje, iż swego syna postanowił wychować według zasad Bożych $^{123}$.

W odróżnieniu od Platona, choć i ten przypomina rodzicom, by uczyli swe dzieci czci bogów ${ }^{124}$, Ojcowie Kościoła proces formacji duchowej budują na dochodzeniu człowieka do wiary. Tak więc Hieronim wspomina o Pauli, która swą córkę Eustochium wychowała na bogatą w łaskę wiary ${ }^{125}$. Z uznaniem wypowiada się także o pewnej matce, która mimo różnych, nawet poważnych zastrzeżeń co do jej postępowania, nauczyła córkę kochać Chrystusa ${ }^{126}$. W innym miejscu zaś przypomina matce, by jej córka, gdy zacznie dorastać, uczęszczała z nią do świątyni i czytała Pismo św., a więc pogłębiała się duchowo ${ }^{127}$.

Jednoznaczne jest również pod tym względem stanowisko Augustyna, który nie tylko zwraca uwagę, by rodzice doprowadzili swe dzieci do wiary i chrztu św. ${ }^{128}$, ale też pochwala troskę o rozwój pobożności i wychowanie dzieci ${ }^{129}$. Sam daje temu przykład, kiedy to wraz ze swym synem, którego określa, „towarzyszem i rówieśnikiem swego ojca w lasce”, kształcił się w zasadach wiary chrześcijańskiej, razem też przyjął chrzest ${ }^{130}$. Ze słowami pełnymi

\footnotetext{
119 Por. Enarrationes in Psalmos 37, 24.

120 Por. Epistula 107, 6.

121 Por. Epistula 128, 1.

122 Por. Epistula 107, 9.

123 Por. Confessiones IX 6.

124 Por. Respublica III 1, 386a.

125 Por. Epistula 108, 2.

126 Por. Epistula 117, 4.

127 Por. Epistula 107, 7.

128 Por. Enarrationes in Psalmos 50, 24.

129 Por. De bono viduitatis 18.

130 Por. Confessiones IX 6.
} 
wdzięczności wypowiada się tu o swej matce, która, jak czytamy, urodziła go cieleśnie wydając na świat, jak i duchowo - wprowadzając do światłości wiecznej $^{131}$.

W opinii bowiem biskupa Hippony małżeństwo jest wtedy wartościowe, a małżonkowie w nim złączeni o tyle są lepsi, o ile będąc czyści i wierniejsi, lękają się Boga, zwłaszcza, jeżeli żywią duchowo dzieci, które pragną mieć według ciała ${ }^{132}$. Wartość małżeństwa, jak w innym miejscu przekonuje nas Augustyn, polega więc nie tylko na wydaniu na świat potomstwa, ale także na jego godziwym, uczciwym i czystym zrodzeniu oraz na ustawicznym i nastawionym na zbawienie wychowaniu ${ }^{133}$. Formacja duchowa nie może też pominąć obecności w życiu człowieka modlitwy, która nie tyle winna być zanoszona do Boga w intencjach doczesnych, ale i tych, które czynią człowieka dobrym i szczęśliwym. Czynić zaś to winien nie tylko sam wychowanek, ale także jego rodzice ${ }^{134}$.

\section{METODY WYCHOWAWCZE}

Ukazane w poprzednich paragrafach poglądy naszych autorów na temat obowiązku wychowania, ich ocena samego procesu wychowawczego jak i celów wychowawczych, skłania do pytania o ich stanowisko dotyczące metod wychowawczych, które pozwalają te cele osiągnąć. Stąd też ten ostatni punkt naszego opracowania będzie próbą odpowiedzi na to pytanie.

1. Upomnienie. Jedną z metod wychowawczych, jak możemy dowiedzieć się z lektury pism naszych autorów, jest upomnienie. Pisze o tym Augustyn ${ }^{135}$, a przede wszystkim Platon, który zauważa, że człowiek, gdy spotka się z upomnieniem czy naganą, na przykład ze strony ojca, zaczyna w pierwszej chwili się buntować, popada w rozterkę, by w końcu rozpocząć ze sobą walkę, której skutek jest pozytywny; niektóre pożądania, a nawet nałogi, jak to potwierdza $\operatorname{Augustyn}^{136}$, zanikają, w duszy zaś dokonuje się ład, a więc urzeczywistnia się harmonia, o której również mówił ten starożytny filozof ${ }^{137}$.

131 Por. Confessiones IX 8.

${ }^{132}$ Por. De bono coniugali 19, 22, przekład polski: W. Eborowicz (Św. Augustyn, Wartość matżeństwa, w: Św. Augustyn, Antologia pism o małżeństwie i rodzinie, część I, Pelplin 1980), s. 7475.

133 Por. De sancta virginitate 12.

134 Por. De ordine II 20, 52, CCL 29, 135-136, przekład polski: J. Modrzejewski (O porządku, Warszawa 1953, t. I), s. 225; Hieronymus, Epistula 107, 10.

135 Por. Confessiones IX 9.

136 Por. Confessiones IX 8.

137 Por. Respublica VIII 13, 560e. 
Upomnienie jednak nie odnosi się tylko, jak potwierdza to także Platon, do wychowanka, ale skierowane jest również do wychowawcy. Nie można, jak czytamy, nauczyć młodego człowieka poczucia honoru, jedynie przez powtarzane uwagi czy wymówki, że zachowuje się niewłaściwie, lub stałe przypominanie, by zachowywał się odpowiednio. Według Platona to wychowawcom należy przypominać o tym, by wstydzili się młodych i wystrzegali się, żeby nie widzieli ich oni nigdy, ani nie słyszeli mówiących lub czyniących coś niewłaściwego $^{138}$. Możemy więc powiedzieć, że wychowawca ma nie tylko upominać wychowanka, ale także upomnienia kierować pod swoim adresem. Innymi słowy, oboje, jak to już uczył Sokrates, mają podążać w tym samym kierunku.

2. Przymus fizyczny. Lektura cytowanych dzieł przedstawicieli starożytności pokazuje, iż w tamtych czasach jak i we współczesnych, dziecko często sprzeciwia się swoim rodzicom i nauczycielom, okazując im nieposłuszeństwo, gdyż niekiedy chęć zabawy jest większa niż pragnienie zdobywania wie$\mathrm{dzy}^{139}$. Reakcją na to, jak zauważa Augustyn, jest surowe karcenie ${ }^{140}$, a nawet bicie dziecka zwłaszcza, gdy zaniedbuje się ono w nauce, nie spełniając tym samym planów, jakie wobec niego mają jego rodzice ${ }^{141}$.

Nad tym, czy tego rodzaju metoda wychowawcza jest właściwa, zastanawiał się już Platon. Zauważał on, iż rozpieszczanie małych dzieci wpływa negatywnie na ich usposobienie, czego wyrazem są częste u nich objawy niezadowolenia, łatwo popadają w złość, a najmniejszy nawet powód wprawia je w rozdrażnienie. Z drugiej jednak strony uczeń Sokratesa miał świadomość, iż surowe postępowanie, trzymanie w karbach sprawia, że zamykają się one jakby w sobie, stają się niezdolne do szlachetniejszych porywów, nie żywią życzliwości do ludzi i nie nadają się przez to do „obcowania z nimi i dobrego współżycia" 142 .

Odpowiedzi na to pytanie szukał również Augustyn. W kontekście wypowiedzi na temat zbawiennych biczy Bożych, za które człowiek winien być Bogu wdzięczny ${ }^{143}$, autor zauważył, że jeżeli nad dzieckiem jest ręka ojcowska, a ono jest dobrym synem, to nie powinno gardzić dyscypliną, gdyż ojciec wartość syna zdobywa poprzez wychowywanie jego w karności. Stąd też, jego zdaniem, nie powinien oszczędzać rózgi, pamiętając jednak o obowiązku miłosierdzia. $\mathrm{Z}$ kolei dziecko skoro dobrze poznało obietnicę ojca, jaką jest dziedzictwo, które ma otrzymać, nie powinno lękać się rózgi, ale wydziedziczenia, gdyż,

138 Por. Leges V 729b.

139 Por. Confessiones I 10.

140 Por. Confessiones IX 8.

141 Por. Confessiones I 10; Enarrationes in Psalmos 22, 5, PSP 37, 179. Tutaj Augustyn przyznaje się, iz będąc dzieckiem „był uczony przez rózgę”.

142 Por. Leges VII 791d, tłum. Maykowska s. 279.

143 Por. Enarrationes in Psalmos 54, 2. 
zdaniem biskupa Hippony, lepiej jest zostać doświadczonym rózgą ojca, niż zginąć od zabójców wśród pochlebstw ${ }^{144}$.

Autor Wyznań w pierwszym rzędzie uważa więc, że sama kara nie jest czymś negatywnym, zwłaszcza gdy celem jest poprawa postępowania dziecka. Jego zdaniem, biorąc pod uwagę młody wiek niedorosłego jeszcze potomka, nie należy się obawiać występowania tutaj jakiś objawów nienawiści po stronie rodziców, ale troski o jego rozwój moralny ${ }^{145}$. Tak więc towarzyszący wymierzaniu kary gniew ${ }^{146}$ nie jest jeszcze, zdaniem biskupa Hippony, nienawiścią, ale, jak to czytamy w innym miejscu, troską ojca, by syn przez złe życie i obyczaje nie utracił zachowywanego i przygotowywanego dla niego dziedzictwa ${ }^{147}$. Autor Objaśnień Psalmów uważa również, że należy uznawać wymierzaną przez ojca karę, nie należy też szemrać przeciwko tej ręce, która poprawia po to, by dzieci nie pozostały złymi, i by nie zasłużyły na wydziedziczenie, by stały się prawymi, czyniącymi to co się Bogu podoba, a także by w przeciwnościach potrafiły Jego wychwalać ${ }^{148}$. Kontynuując te refleksje, a jednocześnie starając się odnaleźć motywację takiego stanowiska, Augustyn zauważa, że gdyby syn zbrzydł ojcu lub został przez niego znienawidzony, to ten przestałby go karcić. Z przemyśleń Augustyna wynika więc, że należy składać dzięki karcącemu ojcu po to, by w przyszłości otrzymać dziedzictwo przyobiecane od Boga, który także karci za popełnione grzechy ${ }^{149}$. W kontekście tych stwierdzeń nie dziwi fakt, iz Augustyn nie ocenia krytycznie postępowania ojca, który policzkuje swego syna, bije, szarpie za uszy, chwyta za rękę i prowadzi do szkoły ${ }^{150}$. Postępowanie bowiem ojca wobec syna podobne jest, zdaniem naszego autora, do boskiej pedagogii, mającej na celu oczyszczanie człowieka z nieprawości i napełnianie łaską. Szczególnie zaś ma to miejsce wtedy, gdy syn gardzi nakazami swego ojca.

Innego zdania jest jednak Hieronim. Uważa on, iż nie powinno się karcić dziecka w przypadku opieszałości, ale poprzez pochwały oddziaływać na nie pozytywnie, pobudzać $w$ nim zdolności, by cieszyło się ono ze sukcesów a smuciło z powodu niepowodzeń. Postępowanie przeciwne, a więc wymierzane kary, może odnieść zupełnie odwrotny skutek - dziecko całkowicie zniechęci się do nauki, a wręcz ją znienawidzi ${ }^{151}$. Tymczasem, jak przekonuje nas Hieronim, dziecko winno kochać to, czego musi się uczyć, aby to, co wykonu-

${ }^{144}$ Por. Enarrationes in Psalmos 88, (2) 2.

145 Por. De sermone Domini in monte I 20, 63, tłum. S. Ryznar, PSP 48, 63-64.

146 Por. Quaestionum in Heptateuchum libri VII 4, 49, przekład polski: J. Sulowski (Św. Augustyn, Problemy Heptateuchu, cz. I, Warszawa 1990, cz. 2, Warszawa 1990, PSP 46 i 47).

147 Por. Enarrationes in Psalmos 30, (3) 4; 54, 2.

148 Por. Enarrationes in Psalmos 32, (2) 3.

149 Por. Enarrationes in Psalmos 48, (2) 9.

${ }^{150}$ Por. Enarrationes in Psalmos 55, 15.

151 Por. Epistula 107, 4. 
je, nie było dla niego ciężarem, lecz przyjemnością, czynnością spełnianą nie z konieczności, lecz z ochoty ${ }^{152}$.

3. Dialog. Metodą wychowawczą, której nasi autorzy poświęcili stosunkowo dużo miejsca, jest prowadzony z dzieckiem czy młodym człowiekiem dialog. Taki charakter miały dialogi czy dysputy filozoficzne, które prowadził ze swymi uczniami Sokrates. Jako wychowawca młodzieży ateńskiej pragnął właśnie tą drogą osiągnąć postawiony sobie cel, jakim było ostatecznie doprowadzenie często poszukującego i zagubionego człowieka do prawdy. Rodzic, który jest zainteresowany postępowaniem dziecka, jak to widzimy u Augustyna na przykładzie zachowania się jego matki, często przeżywa ból, ilekroć widzi, gdy odchodzi ono od Boga ${ }^{153}$. Ta troska o dziecko, jak potwierdza to z kolei Hieronim, ma swe źródło w miłości, którą się jego obdarza ${ }^{154}$.

Znaczenie prowadzonego $\mathrm{z}$ dzieckiem dialogu rozumiał biskup Hippony. Nie chodziło mu w tym tylko o to, by rodzic na przykład dowiadywał się od dziecka, w jaki sposób nauczyciel je traktuje ${ }^{155}$, lecz by były to często rozmowy bardzo głębokie na temat szczęścia w życiu człowieka, prowadzone w tym celu, by dziecko nakłonić do myślenia, rozwinąć w nim, jak czytamy, siły i wyostrzyć wzrok umysłu, po to, by „nie tylko wytrzymało, ale i pokochało ciepło i blask tych krain, w których istnieje życie szczęśliwe"156.

W końcu dialog, jak już na to wskazuje sama nazwa, musi być też obustronny, to znaczy również wychowanek ma prawo pytać czy wypowiadać swe opinie, a nawet prośby ${ }^{157}$.

4. Przykład osobisty. Z lektury pism naszych autorów wynika, iż w ich przekonaniu o skuteczności wychowania decyduje osobisty przykład wychowawcy. Nie można się więc dziwić, iż tej właśnie metodzie wychowawczej poświęcili oni dużo miejsca w swych pismach. Ich zdaniem, osobisty przykład powinni swym dzieciom dawać w pierwszym rzędzie rodzice, którzy winni być dla nich wzorem do naśladowania. Postępowanie rodziców, jak to podkreśla Hieronim, nie może prowadzić dziecka do grzechu, a więc naśladowania ich w złym. Stąd też, autor ten formułuje pewnego rodzaju zasady, którymi rodzice winni się kierować w postępowaniu wobec swych dzieci. Należy do nich świadomość, że bardziej uczą przykłady, niż wypowiadane przez nich pouczenia ${ }^{158}$.

152 Por. Epistula 128, 1.

153 Por. Confessiones IX 9.

154 Por. Epistula 22, 20.

155 Por. De magistro 14, 45, CCL 29, 202, przekład polski: J. Modrzejewski (O nauczycielu, w: Św. Augustyn, Dialogi filozoficzne, t. 3, Warszawa 1953) s. 69.

156 Por. De magistro 8, 21, CCL 29, 180, tłum. Modrzejewski s. 45.

157 Por. Augustinus, De ordine II 20, 52. 
To właśnie dziecko, jak czytamy u tego Ojca Kościoła, winno uczyć się postępowania od matki, a nie matka od córki ${ }^{159}$.

W podobnym duchu wypowiadał się także Augustyn, który negatywnie oceniał złe, a nawet rozwiązłe postępowanie ojca, które stanowi zły przykład dla dziecka i świadczy, że ojciec nie spełnia tego, co należy do jego obowiązków wychowawczych $^{160}$.

Ten problem rozumiał także Platon, który dostrzegał niebezpieczeństwo złego przykładu jakie grozi dziecku ze strony rodzica, który wielką wagę przypisuje na przykład, do dóbr materialnych i przyjemności. Skutkiem takiego właśnie postępowania może być ukształtowana skłonność dziecka do popełniania wszelkiego $z^{16}{ }^{161}$. Takim negatywnym przykładem jest dla Platona postępowanie króla perskiego Dariusza I (VI/V w. prz. Chr.), który swego syna Kserksesa wychowywał w zbytku, co stało się, zdaniem autora, przyczyną jego późniejszych niepowodzeń. Tego rodzaju wychowanie, jak czytamy, nigdy nie zaowocuje u dziecka cnotą ${ }^{162}$, gdyż człowiek źle wychowany, skłonny do popełniania zła, takiego postępowania będzie uczył również swe dzieci ${ }^{163}$. Tymczasem dziecku, zdaniem Platona, należy przekazać w spuścí́nie nie tyle złoto ${ }^{164}$, co poczucie honoru i wstydu ${ }^{165}$. Brak bowiem poczucia wstydu u dorosłych sprawia, że młody człowiek zatraci go zupełnie. Dlatego też autor dialogów stara się przypominać to, co później powtórzyli Ojcowie Kościoła, że najlepszy sposób wychowywania młodych i jednocześnie siebie samego, nie polega na upominaniu, ale na pokazaniu, że to, do czego się nawołuje i zachęca młodego człowieka, samemu należy czynić ${ }^{166}$.

Negatywny wpływ wychowawczy wywiera także przenoszenie konfliktów rodziców na dzieci. Chodzi tu o to, jak zauważa Platon, by rodzice nie skarżyli na siebie przed swymi dziećmi ${ }^{167}$. Innymi słowy, temu przedstawicielowi starożytności niechrześcijańskiej zależało bardzo na tym, by w rodzinie, także szeroko rozumianej, bo biorącej pod uwagę również domowników, stworzyć właściwy klimat wychowawczy, i to taki, by młody człowiek widząc różne zachowania, nie czuł w sobie wewnętrznego rozdarcia, które to często owocuje przekorą, lub kształtuje charakter dumny i ambitny ${ }^{168}$.

158 Por. Epistula 107, 9, CSEL 55, 300:, ,[...] mementote vos parentes virginis et magis eam exemplis docere posse quam voce".

${ }^{159}$ Por. Epistula 117, 11.

160 Por. Enarrationes in Psalmos 50, 24.

161 Por. Respublica IX 2, 572c.

162 Por. Leges III 695d-696e.

163 Por. Respublica IX 2, 572de.

164 Por. Leges V 729b.

165 Por. Leges V 729c.

166 Por. Leges V 729c.

${ }^{167}$ Por. Respublica VIII 5, 549cd.

${ }^{168}$ Por. Respublica VIII 5, 550b. 
W świetle wyżej przytoczonych spostrzeżeń, potwierdzonych przykładami zaczerpniętymi z życia $\mathrm{i}$ historii, słuszną wydaje się nam uwaga Hieronima, który przypomina, że opiekunem i wychowawcą dzieci winien być człowiek godny ${ }^{169}$, głęboko wierzący ${ }^{170}$, znany z dobrych obyczajów i mogący poprzez świadectwo swego życia, stanowić przykład dla innych ${ }^{171}$, gdyż dobre wychowanie jest zasługą w oczach Bożych ${ }^{172}$ i zachętą do dobrego postępowania ${ }^{173}$, zwłaszcza, gdy podbudowane jest modlitwą wychowującego w intencjach wychowanka ${ }^{174}$.

$* * *$

1. Przeprowadzona analiza porównawcza cytowanych pism pozwala zauważyć, iż Ojcowie Kościoła do pierwszorzędnych obowiązków ciążących na rodzicach zaliczali wychowywanie dzieci i młodzieży. Swym stanowiskiem różnili się od poglądów Platona, który wykonywanie tego zadania zlecał przede wszystkim państwu, przyznając mu w tej materii rolę dominującą.

2. Proces wychowawczy, jak to wynika $z$ analizy dzieł naszych autorów, winien mieć charakter powszechny, ustawiczny i przebiegać na najwyższym poziomie. Wymaga on jednak umiejętności, zwłaszcza w psychologicznym podejściu do dziecka. Stąd też tak Platon, jak i Ojcowie Kościoła, kładli szczególny nacisk na konieczność doboru odpowiednich wychowawców i nauczycieli. Brak z kolei zainteresowania się dzieckiem ze strony rodziców nie tylko odbija się negatywnie na psychice dziecka, ale sprawia, że staje się ono nie przystosowane do życia w społeczeństwie.

3. Kolejnym zagadnieniem, które było przedmiotem naszego zainteresowania, stanowiły cele wychowawcze. Z lektury analizowanych pism wynika, iż należały do nich formacja fizyczna, intelektualna, filozoficzna, etyczna oraz duchowa. Punktem odniesienia tej formacji dla Platona było najwyższe Dobro, zaś dla Ojców Kościoła - Bóg.

Gdy chodzi o formację fizyczną to na jej temat wypowiadał się jedynie Platon. Z jego wypowiedzi wynika jednak, iz wychowanie fizyczne przyszłego wodza państwa stanowiło tylko element przygotowujący do formacji filozoficznej.

Tak Platon, jak i Ojcowie Kościoła, dużą wagę przywiązywali do formacji intelektualnej. Nie była ona jednak dla nich celem sama w sobie, gdyż dla

\footnotetext{
169 Por. Epistula 107, 3.

${ }^{170}$ Por. Epistula 125, 6.

171 Por. Epistula 107, 4. 9.

172 Por. Epistula 79, 7.

173 Por. Augustinus, De ordine II 20, 52.

174 Por. tamże.
} 
Platona była nim kontemplacja Dobra, dla Ojców Kościoła Bóg. To oglądanie oczyma rozumu Dobra, czy osobisty w duchu wiary kontakt z Bogiem, miały na celu uformowanie człowieka dobrego: dla Platona wodza państwa, dla Ojców Kościoła wiernego chrześcijanina, który żyje zasadami swej wiary. Tak więc kontakt z tym, co boskie, miał nie tylko wymiar osobisty, ale społeczny, co wyraźnie dostrzec można było w wypowiedziach Platona na temat przebiegu formacji filozoficznej.

Z kolei więcej miejsca, w porównaniu z Platonem, poświęcili w swych wypowiedziach Ojcowie Kościoła zagadnieniu formacji etycznej, której celem było wychowanie dobrego człowieka i chrześcijanina, bogatego bogactwem cnót, która to formacja, tak jak u Platona filozoficzna, miała wymiar osobisty i skutki społeczne.

Kompleksowe wychowanie człowieka nie może się ograniczać tylko do formacji fizycznej czy intelektualnej, ale musi objąć również sferę duchową. Dostrzegał to, oczywiście w kontekście swej filozofii Platon, potrzebę tego widzieli Ojcowie Kościoła, gdyż i ta sfera życia człowieka ma swój wymiar społeczny. W odróżnieniu od Ojców Kościoła Platon troskę o duszę człowieka uzasadniał tylko racjonalnie, zaś Ojcowie Kościoła to zagadnienie rozpatrywali przede wszystkim na płaszczyźnie wiary i osobowego poprzez modlitwę tak rodziców jak i dzieci kontaktu z Bogiem.

4. Ostatni punkt naszego opracowania miał za cel ukazanie metod wychowawczych, które winni stosować wobec swych dzieci i wychowanków nie tylko rodzice, ale i wychowawcy. Lektura analizowanych tekstów pozwala na wyróżnienie czterech metod, do których należą: upomnienie, przymus fizyczny, dialog oraz przykład osobisty.

Na temat pierwszej z tych metod wypowiadał się prócz Augustyna przede wszystkim Platon. Jej celem jest urzeczywistnienie w człowieku harmonii. Upomnienie nie może być tylko kierowane pod adresem wychowanka, ale winno również ono dotyczyć wychowawcy, który spełni swe zadanie wtedy, gdy będzie zachowywał w swym życiu to, czego sam naucza.

Autorzy starożytni stawiali sobie również pytanie, czy wobec wychowanka należy stosować przymus fizyczny czy też nie. Pod tym względem Platon nie zajął wyraźnego stanowiska. Przeciwny był jednak zbytniemu rozpieszczaniu, jak i surowemu traktowaniu dziecka. W przeciwieństwie do Platona, Augustyn nie sprzeciwiał się stosowaniu kary wobec dziecka, która miała poprawić jego postępowanie, przypominał jednak o obowiązku miłosierdzia. Odmiennego zdania był jednak Hieronim: uważał on, że wychowawcze oddziaływanie nie powinno stosować kar, lecz zachęty do pozytywnego postępowania.

Tak Platon, jak i Ojcowie Kościoła pozytywnie wypowiadali się na temat dialogu prowadzonego $\mathrm{z}$ wychowankiem oraz wychowanka $\mathrm{z}$ rodzicami i wychowawcami, którego celem było nauczenie samodzielnego i krytycznego myślenia, a w konsekwencji, doprowadzenie do odkrycia prawdy i Boga. 
Analiza pism naszych autorów ukazała, iż proces wychowawczy odniesie zamierzony skutek wtedy, gdy wychowawca lub rodzic będą dawać dziecku osobisty przykład właściwego postępowania oraz pokazywać swym życiem to, czego chcą nauczać.

\section{ASPETTI EDUCATIVI NEGLI SCRITTI FILOSOFICI DI PIATONE E DEGLI AUTORI CRISTIANI DEL IV SECOLO}

(S. AGOSTINO, S. GIROLAMO)

(Sommario)

Il presente studio ci fa convincere che per i Padri della Chiesa in confronto di Platone l'educazione dei bambini e della gioventù costituiva il primario dovere dei genitori. Platone prima di tutto attribuiva questo ruolo allo stato. Il processo educativo il quale esige le capacità del modo psicologico del trattare dell' uomo dovrebbe riguardare tutti e svolgersi all'altissimo livello. Perciò è molto importante la scelta dei adeguati educatori e dei maestri ed anche la necessità dell'interessamento del bambino da parte dei genitori. La mancanza di questo riflette negativamente sulla psicologia del bambino causando un negativo adattamento alla vita nella società umana.

L'analisi dei giudizii degli autori antichi ci dimostra che essi come lo scopo educativo hanno considerato la formazione fisica, intelletuale, filosofica e spirituale. Il punto di riferimento di questa per Platone era un sommo bene, invece per i Padri della Chiesa il Dio. Sulla formazione fisica si ha pronunciato soltanto Platone secondo cui essa costituiva un elemento preparatorio per la formazione filosofica del futuro comandante dello stato. Lo scopo della formazione intelletuale per Platone è stata la contemplazione del Bene, per i Padri della Chiesa, il Dio. Il frutto di questa formazione, in modo simile come nella formazione etica di cui Padri della Chiesa hanno dedicato la maggiore attenzione, doveva essere un buon uomo: per Platone il comandante dello stato, per Padri della Chiesa un fedele cristiano vivente secondo dei principi della fede. Così il contatto con divino aveva non soltanto una dimensione personale ma anche sociale. L'educazione complessiva dell' uomo, come risulta dall'analisi degli scritti degli autori antichi, dovrebbe pure riguardare la sfera spirituale la quale non è priva della sua dimensione sociale.

Dagli scritti da noi esaminati ne risulta che nella antichità siano state applicate tali metodi educativi come ammonizione, coazione fisica, dialogo ed esempio personale. Sul primo metodo all'infuori di Agostino ha parlato anzitutto Platone secondo cui lo scopo di questo metodo era una attuazione di armonia nell'uomo stesso. Secondo del parere dei nostri autori l'ammonizione concerne non soltanto allievo ma anche il parente ed educatore il quale dovrebbe osservare nella sua vita tutto ciò 
che lui stesso insegna. Per quanto riguarda l'uso di coazione fisica Platone era contrario allo vezzeggiamento eccessivo da una parte e rigido trattamento del bambino dall'altra. Agostino invece non essendo contrario all'uso della coazione fisica verso del bambino ricordava il dovere della misericordia. Girolamo invece era d'opinione diversa. Secondo il suo parere l'influsso educativo non dovrebbe utilizzare delle punizioni ma incoraggiamenti. Padri della Chiesa così come Platone si hanno pronunciati in modo positivo sull dialogo condotto con allievo ed allievo con genitori ed educatori di cui scopo era un insegnamento ad un indipendente e critico modo di pensare e in conseguenza la scoperta della verità e di Dio. 